\title{
Common and Antarctic Minke Whales: Conservation Status and Future Research Directions
}

OPEN ACCESS

Edited by: Rob Harcourt,

Macquarie University, Australia

Reviewed by:

Luis Cardona,

University of Barcelona, Spain

Salvatore Cerchio,

New England Aquarium,

United States

*Correspondence:

Denise Risch

denise.risch@sams.ac.uk

Specialty section:

This article was submitted to

Marine Megafauna,

a section of the journal

Frontiers in Marine Science

Received: 07 December 2018

Accepted: 24 April 2019

Published: 14 May 2019

Citation:

Risch D, Norris T, Curnock $M$ and

Friedlaender A (2019) Common and Antarctic Minke Whales: Conservation Status and Future

Research Directions.

Front. Mar. Sci. 6:247.

doi: 10.3389/fmars.2019.00247

\author{
Denise Risch ${ }^{1 *}$, Thomas Norris ${ }^{2}$, Matthew Curnock ${ }^{3}$ and Ari Friedlaender ${ }^{4}$ \\ ${ }^{1}$ Scottish Association for Marine Science, Oban, United Kingdom, ${ }^{2}$ Bio-Waves, Inc., Encinitas, CA, United States, \\ ${ }^{3}$ Commonwealth Scientific and Industrial Research Organisation Land and Water, Townsville, QLD, Australia, ${ }^{4}$ Institute for \\ Marine Sciences, University of California, Santa Cruz, Santa Cruz, CA, United States
}

Minke whales comprise some of the most widely distributed species of baleen whales, some populations of which are still regularly targeted by commercial whaling. Here, we review the conservation status of common (Balaenoptera acutorostrata) and Antarctic (Balaenoptera bonaerensis) minke whale populations, against the backdrop of ongoing whaling operations and other anthropogenic threats, including climate change, entanglement in fishing gear, ship strikes, and noise pollution. Although some coastal minke whale populations have been studied in detail, others, which inhabit remote and ecologically sensitive locations, such as the Antarctic ice shelf, are among the least understood populations of marine mammals. The unresolved taxonomy of dwarf minke whales further highlights some of the existing knowledge gaps concerning these species. Due to their relatively small size and elusive behaviors, large uncertainties exist for almost all minke whale populations with respect to behavior, migratory routes and winter distributions, hindering effective conservation and management. However, recent advances in research technology, such as passive acoustic monitoring (PAM), unmanned aerial systems (UAS), multisensor recording tags, and machine learning assisted photo-identification, are increasingly being applied to study minke whales and their habitat, and are starting to open new windows into their life history and ecology. In future research, these non- and less-invasive methods should be integrated in larger-scale comparative studies aiming to better understand minke whale behavior, ecological interactions and their varying habitats to drive and support effective species conservation.

Keywords: population status, minke whales, Antarctic minke whale, conservation, future research

\section{INTRODUCTION}

Many baleen whale populations have been reduced extensively by whaling, which makes them more vulnerable to negative impacts from changes in their habitats (Baker and Clapham, 2004). In the case of minke whales, several populations are still being impacted by ongoing commercial whaling. These hunts are carried out against the backdrop of global climate change and other anthropogenic impacts, such as interactions with fisheries, pollution, as well as ship strike. Given this complex array of often interacting threats and considering their comparatively long life spans, minke whales, like other baleen whales, face significant challenges that may lead to severe impacts on populations. 
Minke whales inhabit all oceans, including tropical as well as polar waters (Figure 1). Since the late 1990s, two different species have been recognized: the common minke whale (Balaenoptera acutorostrata) and the Antarctic minke whale (Balaenoptera bonaerensis). Molecular data suggests that the two species are sister taxa and their clade is sister to the other Balaenopteridae and the gray whale (Eschrichtius robustus) (Rychel et al., 2004) but there is still some ambiguity about the phylogenetic relationships of minke whales to other species (Perrin et al., 2018). For the common minke whale three putative subspecies have been proposed; Balaenoptera acutorostrata acutorostrata in the North Atlantic, Balaenoptera acutorostrata scammoni in the North Pacific and the dwarf minke whale, unnamed subspecies, in the Southern hemisphere (Rice, 1998). Dwarf minke whales were first recognized as a distinct form of the common minke whale in the mid-1980s (Best, 1985), and genetic evidence suggests the existence of at least two different populations in the Southern Hemisphere (Pastene et al., 2010). The exact placement of the dwarf minke whales in the taxonomy of this species complex is still unclear. For example, South Atlantic dwarf minke whales are more closely related to North Atlantic common minke whales, than either are to dwarf minke whales from the South Pacific, indicating that their subspecies status needs further study (Pastene et al., 2010).

The seasonal distribution and migration patterns of nearly all populations of minke whales are poorly understood. Their small size, inconspicuous behavior and seasonal distribution in remote pelagic and sea ice habitats contribute to this lack of understanding. Existing knowledge is often obtained from studying populations that frequent coastal habitats or based on incomplete historical whaling records. At least some proportion of the population of minke whales in the western North Atlantic appear to migrate to the Caribbean during winter (Mitchell, 1991;
Risch et al., 2014a). The Gulf of St. Lawrence is a known summer feeding habitat (Lynas and Sylvestre, 1988; DoniolValcroze et al., 2007). In the central North Atlantic, pronounced sexual segregation exists on higher latitude feeding grounds, with females occurring further north, off western Greenland, while males remain further south and to the east of Greenland (Laidre et al., 2009). Tracks of satellite-tagged minke whales indicate a southward movement, following the mid-Atlantic ridge, as far south as at least $28^{\circ} \mathrm{N}$ starting in autumn (September to November) (Víkingsson and Heide-Jørgensen, 2015). During summer and early fall (June to November), minke whales in the eastern North Atlantic occur around the British Isles (Macleod et al., 2004; Tetley et al., 2008; Risch et al., 2019) and Norway (Heide-Jørgensen et al., 2001), while their winter distribution remains largely unknown. However, minke whales have been observed year-round around the Canary Islands (van Waerebeek et al., 1999), but only occasionally off Portugal, Spain and West Africa (Aguilar et al., 1983; van Waerebeek et al., 1999). The species is a relatively rare visitor in the Mediterranean basin with one sighting reported from the Black Sea (Reeves and Notarbartolo di Sciara, 2006).

In the North Pacific, minke whales are widely distributed north of $30^{\circ} \mathrm{N}$, shifting their distribution northward during summer (Zerbini et al., 2006). However, they also occur year-round off central California (Dorsey et al., 1990). In the Central and Eastern Pacific, acoustic data suggest minke whale presence from approximately $15-35^{\circ} \mathrm{N}$ in deep waters surrounding subtropical volcanic islands and atolls during winter and spring (Rankin and Barlow, 2005; Rankin et al., 2007; Oswald et al., 2011; Norris et al., 2017). Data from Korea and Japan indicate seasonal southbound migrations in the western North Pacific, with unknown final destinations (Ohsumi, 1983).

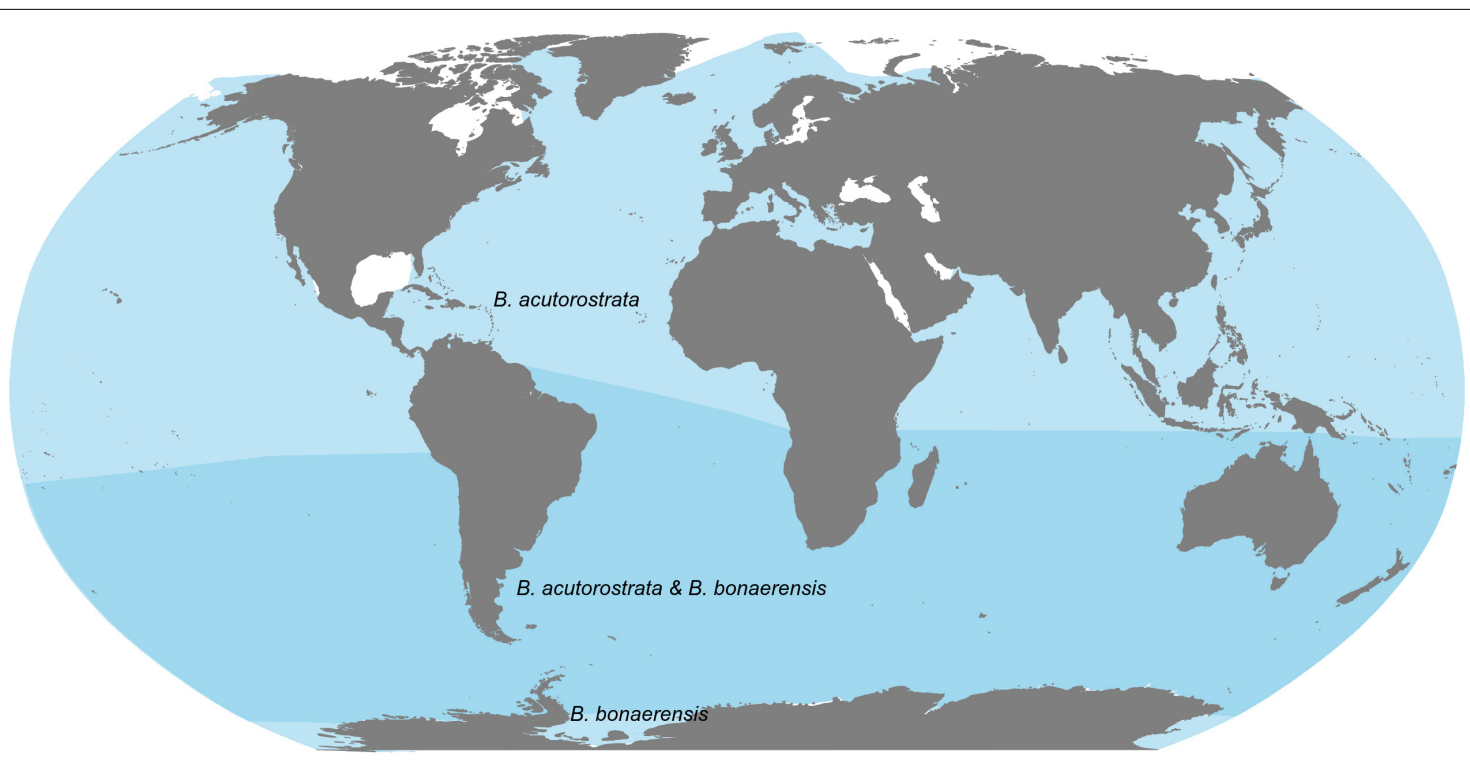

FIGURE 1 | Range map of Common (Balaenoptera acutorostrata) and Antarctic (Balaenoptera bonaerensis) minke whales. Source for presented species ranges: International Union for Conservation of Nature (IUCN) (Cooke et al., 2018a,b). 
The distribution of dwarf minke whales spans the entire southern hemisphere (Figure 1). They have been visually recorded in coastal waters of South America and South Africa in the Atlantic (Zerbini et al., 1996; Acevedo et al., 2006) and in waters off both western and eastern Australia, New Zealand, and New Caledonia in the Pacific (Dawson and Slooten, 1990; Arnold, 1997; Garrigue and Greaves, 2001; Gedamke et al., 2001). Although they are less commonly observed south of $65^{\circ} \mathrm{S}$ than Antarctic minke whales (Branch and Butterworth, 2001), dwarf minke whales are sympatric with Antarctic minke whales in much of their range (Acevedo et al., 2011), which renders some of the visual based information on the distribution of both species ambiguous or inaccurate, due to missing or incorrect identification to species level at sea (Cooke et al., 2018a).

Antarctic minke whales have a circumpolar distribution south of $60^{\circ} \mathrm{S}$ during summer (Figure 1), with high densities reported in parts of the Weddell and Ross Seas (Kasamatsu et al., 1995). The species is highly associated with sea ice and is generally less abundant in ice-free waters (Herr et al., 2019). Recent acoustic data show detections of the species in association with sea ice for most of the year (Dominello and Široviæ, 2016). However, this species has also been observed and recorded in sub-tropical waters of the South Atlantic, South Pacific, and Indian Ocean during winter (McCauley, 2004; Cerchio et al., 2018). A bi-modal temporal distribution pattern of Antarctic minke whales has been visually observed off South Africa, peaking in fall and spring, suggesting migratory movements by parts of the population to lower latitude habitats during winter (Best, 1982). There is also some evidence that Antarctic minke whales occasionally occur north of the equator (Glover et al., 2010; De Boer, 2015).

With this review, we aim to summarize current knowledge on the threats global minke whale populations are facing, review current research and monitoring approaches and discuss data gaps and future research and conservation priorities.

\section{THREATS}

\section{Climate Change}

Antarctic minke whales provide a good example of a baleen whale species that are at risk from multiple environmental pressures driven by climate change. The marine ecosystem around the Antarctic Peninsula is experiencing dramatic warming (Morris and Vaughan, 2003) and significant reductions in the extent and duration of seasonal sea ice cover (Stammerjohn et al., 2008, 2011, 2012). These changes affect every component of the ecosystem (Schofield et al., 2010; Ducklow et al., 2012), but particularly the demography, behaviors and ecology of predators that rely on sea ice for foraging habitat and prey, such as Antarctic krill (Euphausia superba). The life history and population dynamics of krill are heavily influenced by climate forcing (Nicol, 2006), so predators of krill must respond to interannual variability in prey availability and alter their behavior and demography in response to such changes (e.g., penguins and seals; Fraser et al., 1992; Reid and Croxall, 2001; Fraser and Hofmann, 2003; Reid et al., 2005). Currently we do not understand how large-scale changes in climate and sea ice cover will affect these ecological relationships, because the linkages between these predators and their prey remain poorly studied (Fraser and Hofmann, 2003).

Antarctic minke whales are the largest ice-dependent krill predators in the Southern Ocean. As their distribution and ecology are directly tied to sea ice (Herr et al., 2019) and foraging on krill, any changes that affect the quantity and quality of their habitat and food availability could be significant. Currently, Antarctic minke whales and humpback whales are thought to partition prey resources in this region by feeding in different habitats (sea ice versus open water) but when the two species do overlap in time and space, they partition prey vertically (Friedlaender et al., 2008). With continued sea ice decline, the potential for overlap, and thus competition for prey, increases as does the likelihood that krill abundance will decrease due to poor recruitment, for example (Atkinson et al., 2004). This could lead to both a limited amount of preferred sea ice habitat and limited prey availability, increasing the potential for competition with other krill predators (including humpback whales (Megaptera novaeangliae), crabeater seals (Lobodon carcinophaga), Antarctic fur seals (Arctocephalus gazella), as well as a variety of penguin, seabird, and fish species). In combination, this could mean that Antarctic minke whales will be displaced to regions that are currently covered by more sea ice and those that remain may be at higher predation risk from killer whales in open water (Higdon and Ferguson, 2009) and be in competition with other predators for a limited prey resource.

\section{Whaling}

Due to their small size and relatively fast movements, minke whales only became a target of industrial whaling operations after the demise of the larger whale species, in the early 1970s (Horwood, 1990). Commercial whaling is carried out by Norway and Iceland (under objection and reservation to the 1986 moratorium agreed by the IWC, respectively), and subsistence hunts carried out by Greenland. Until recently, when Japan decided to leave the IWC (Normile, 2019), whaling for minke whales also continued as part of Japan's special permit ("scientific") whaling programme. Overall, since 1985, 43,799 minke whales have reportedly been killed in commercial $(25,583)$, special permit $(15,176)$ and aboriginal $(5,094)$ whaling programmes, respectively ${ }^{1}$. The scientific whaling by Japan occurred under Article VIII of the International Convention for the Regulation of Whaling (ICRW) and had long been criticized by other member states and scientific expert panels (Gales et al., 2005; Brierley and Clapham, 2016). The criticism, with which the authors of this review are in agreement, called into question the validity of the science being conducted, as well as made the accusation of the use of minke whaling and the sale of its products as a cover up for illegal trade with products from other protected species (Baker et al., 2000, 2010). In 2014 these long-standing concerns led Australia and New Zealand to bring the issue of whether Japan's whaling is legitimately for scientific purposes before the International Court

\footnotetext{
${ }^{1}$ https://iwc.int/home (accessed March 29, 2019).
} 
of Justice (ICJ), which declared in majority that Japan's whaling programme at the time (JARPA II) was not "for the purposes of scientific research." Despite this ruling and continued criticism of lack of scientific justification (Brierley and Clapham, 2016; Clapham, 2017), Japan's current whaling programmes in the Antarctic (NEWREP-A) and North Pacific (NEWREP-NP) were implemented in seasons 2015/16 and 2017/18, respectively, with quotas to kill 333 Antarctic minke whales and 174 common minke whales in the North Pacific ${ }^{2}$. With its decision to leave the IWC, it is anticipated that Japan's current "scientific" whaling programmes will stop and be replaced by a commercial whaling programme in their Exclusive Economic Zone (EEZ) (Normile, 2019).

\section{Ship Strikes}

With the advent of larger, faster moving ships since the 1950s, there has been a steady increase in ship strikes of baleen whales, which is likely to continue to increase as ships become even faster and quieter (Laist et al., 2001; McKenna et al., 2012; Monnahan et al., 2015). Minke whale mortality events attributed to ship strikes are usually characterized as blunt trauma (i.e., from ships colliding with the animal) or propeller cuts and lacerations. A study assessing large whale serious injury and mortality along the east coast of the United States from 1970 to 2009 , documented that 17 out of 396 (4.3\%) of documented minke whale mortality events were due to ship strikes (van der Hoop et al., 2012). Biases and under reporting of ship strike incidents suggest that many more fatal and non-fatal ship strikes occur than are documented (Peel et al., 2018). National and international ship strike databases are now being developed (Cates et al., 2017). More comprehensive, and in some regions, mandatory reporting practices are expected to improve our understanding of this serious problem for whale populations, including minke whales.

\section{Underwater Noise}

Over the last few decades, the potential impacts of humanmade noise in the marine environment have raised concerns and received increased attention from scientists, conservationists, resource managers, policy makers and the public. Sources of anthropogenic noise are numerous and include military and scientific sonar, seismic surveys, underwater explosions, offshore construction and platforms, scientific research, pingers, and acoustic deterrent devices (ADDs), as well as shipping and vessel traffic (Prideaux, 2017). Measurements of ambient noise levels have shown that low-frequency noise has been steadily increasing, based on recordings analyzed from the 1960s to 2000s in the Northeast Pacific (Andrew et al., 2002; McDonald et al., 2006a), and from 2002 to 2012 in the Indian Ocean (Miksis-Olds et al., 2013). These increases in low frequency noise were primarily driven by shipping noise and noise from seismic air guns.

Information about minke whale hearing capabilities is very limited, as audiograms for large whales cannot be measured directly. Predictions of sensitivity to noise are

\footnotetext{
${ }^{2}$ https://iwc.int/home (accessed March 29, 2019).
}

therefore modeled or inferred from species-specific vocalizations, behavioral responses to sounds or anatomical measurements (Mellinger et al., 2000; Tubelli et al., 2012; Yamato et al., 2012; McGarry et al., 2017). Estimates of audiograms for baleen whales, including minke whales, assume highest sensitivities between 200 and 19,000 Hz (National Marine Fisheries Service, 2016). Simulations of the middle-ear transfer function (METF) of the minke whale auditory pathway suggested the best frequency range between approximately 30 and $25,000 \mathrm{~Hz}$ (Tubelli et al., 2012). A recent study in the Northwest Atlantic, investigated the potential of vessel noise to mask baleen whale vocalizations and found an $\sim 80 \%$ loss of communication space for minke whale pulse trains relative to historical "quiet" conditions (Cholewiak et al., 2018). Off Scotland, minke whale densities have been observed to decrease during naval exercises, and mortalities of minke whales occurred during at least two mass stranding events that have been linked to military sonar exercises (Parsons et al., 2000; Balcomb and Claridge, 2001). Minke whales have been observed to respond to mid-frequency active sonar by reducing or ceasing calling and by exhibiting avoidance behaviors (e.g., movement away from the sound source) even at relatively low received sound levels (Martin et al., 2015; Sivle et al., 2015; Kvadsheim et al., 2017). Also, results of a recent behavioral response study indicated that minke whales strongly avoided ADDs that are used in the context of noise mitigation of construction activities (McGarry et al., 2017).

\section{Marine Litter and Chemical Pollution}

Human caused pollution is a pervasive and increasing threat to marine environments (Laist, 1997; Hardesty et al., 2015). It has been estimated that more than six million metric tons of plastic enters the oceans each year; this is predicted to increase 10-fold within the next decade (Jambeck et al., 2015). Ingestion of plastic marine debris has been reported in nine species of baleen whales, including minke whales. Effects range from non-discernible pathological impacts to complete blockage of the digestive tract resulting in malnutrition, starvation and in some cases, mortality (Laist, 1997; Baulch and Perry, 2014). Although levels of persistent organic pollutants (POPs) are decreasing in some populations (Lebeuf et al., 2014), they are of concern to many cetacean species, who may accumulate high concentrations in their blubber (Jepson and Law, 2016). Baleen whales, including minke whales, typically feeding on lower trophic levels than toothed whales, have comparatively lower blubber POP concentrations (Elfes et al., 2010). Nonetheless POPs may have adverse effects on health and reproduction of populations of both species groups (Moon et al., 2010; Hall et al., 2018), especially in combination with other stressors (Côté et al., 2016).

\section{Entanglement in Fishing Gear}

Entanglement in fishing gear is another global problem, affecting a wide range of marine mammal species (Laist, 1997; Read, 2008; Baulch and Perry, 2014; Meager, 2016). Partly due to higher abundance compared to other species in some areas, minke whales are the species most frequently reported dead due to entanglement in fishing gear (Ryan et al., 2016). In Scotland, 
for example, evidence of entanglement in static fishing gear was present in as many as $50 \%$ of stranded minke whales examined from 1990 to 2010 (Northridge et al., 2010). Particularly high levels of by-catch and entanglement of the J stock population of minke whales, inhabiting the Sea of Japan, Yellow Sea, and East China Sea, have raised serious concerns in the IWC Scientific Committee in recent years (International Whaling Commission, 2010; Song et al., 2010). In South Korea, by-caught minke whales can legally be sold and a reporting system has been in place there since 1994. Although reporting of animals is not always accurate, these data show that from 1996 to 2014, minke whales by-caught in Korean waters alone exceeded the estimated level of potential biological removal (PBR) for this population (Song, 2016). Due to their small size, minke whales are more likely to die as a result of entanglement than other species, as they are less likely to be able to reach the surface when weighted down by fishing gear and more often sink after death, which may also lead to under-reporting of entanglement cases for this species (Knowlton et al., 2016). It has been estimated that $70 \%$ of entanglement cases for this species are fatal (Lien, 1994). More recently, several studies have highlighted the long-term consequences of entanglement and animal welfare implications for individuals, often suffering serious health effects over many years, and urged policy and management action to be more inclusive of these issues (Cassoff et al., 2011; Moore and van der Hoop, 2012; Dolman and Moore, 2017; Dolman and Brakes, 2018).

\section{Tourism}

Whale watching tourism with a particular focus on minke whales occurs in several high latitude regions worldwide based on seasonal feeding aggregations (e.g., West Scotland, Iceland, Canada's Gulf of St. Lawrence), as well as in Australia's Great Barrier Reef, which provides habitat for a presumed breeding aggregation of dwarf minke whales (Valentine et al., 2004; O'Connor et al., 2009). Whale watching of minke whales is typically vessel-based, with the Great Barrier Reef case being a unique swim-with activity, that has been managed by the Great Barrier Reef Marine Park Authority since 2003 (Valentine et al., 2004; Mangott et al., 2011; Curnock et al., 2013). To better understand the potential impacts of vessel-based tourism interactions on minke whales and other baleen whales, recent research has focussed largely on behavioral responses to vessels, including changes in swim speed and direction, diving behavior, and decreased time spent resting or feeding (New et al., 2015). Relatively few studies have investigated direct physiological effects associated with disturbance from vessels, including from direct vessel approaches (Christiansen et al., 2014), vessel noise (Erbe, 2002), and vessel pollutants such as oil leaks and exhaust emissions (Lachmuth et al., 2011). While some effects have been inferred, for example increased stress levels and energy expenditure among minke whales in the presence of whale watching vessels (Christiansen et al., 2014), longerterm chronic and cumulative effects of whale watching are of potentially greater concern, but are difficult to assess and thus remain largely unstudied and unknown (Bejder et al., 2006; New et al., 2015).

\section{MONITORING AND RESEARCH APPROACHES}

\section{Visual Monitoring and Behavioral Studies}

Visual monitoring, from boats, ships or airplanes, is still one of the most common approaches to study marine mammal distribution and abundance (Barlow, 2015; Hammond et al., 2017). Despite recent advances in visual monitoring methods (Ferguson et al., 2018), these approaches always will be limited for monitoring animals that spend a large proportion of their lives under water (Borchers et al., 2013; Thomson et al., 2013). In addition, visual surveys are dependent on daylight, and good sighting and weather conditions, and are often spatially restricted to coastal areas. Therefore, they can only provide a snapshot of the true distribution, particularly for far-ranging species such as minke whales (Kaschner et al., 2012). In part due to such limitations and their small size and inconspicuous blows and behavior, knowledge on long-term minke whale distribution and abundance, especially during winter, is still sparse (Best et al., 2012).

Research on dwarf minke whales has largely been based on a small population wintering in the Great Barrier Reef, utilizing dive tourism vessels as platforms of opportunity. Despite the limitations associated with the use of such platforms (i.e., non-systematic survey effort), the ability to study the whales from in-water, and the collection of long-term datasets (e.g., 1996 to present) has enabled a diverse and innovative research programme. Such research has included "interacting population" size estimation using mark-recapture modeling from photoidentified whales (Sobtzick, 2010), population demography via underwater videogrammetry (Sobtzick, 2010) behavioral studies (Mangott et al., 2011), passive acoustic monitoring (PAM) (Gedamke et al., 2001), social and economic valuation of the swim-with-whales tourism activity (Stoeckl et al., 2010), applied research for adaptive management (Curnock et al., 2013), and recently, genetics, migration and habitat use studies via biopsies and satellite-tagging (Birtles et al., 2015).

\section{Photo-Identification}

Photo-identification has been used to recognize and re-sight individual common minke whales since the late 1970s (Dorsey, 1983). Individual identification from surface photography typically relies on clear images of dorsal fin profiles, body scars and pigmentation patterns, and the technique has been used to establish seasonal and inter-annual site fidelity and residency times in a number of feeding areas, for example the east and west coasts of North America (Dorsey, 1983; Stern et al., 1990), and the Isle of Mull, Scotland (Gill et al., 2000). Underwater photo-identification of dwarf minke whales in Australia's Great Barrier Reef, ongoing since 1996 (Arnold and Birtles, 1999), is based primarily on lateral pigmentation patterns which have been shown to have sufficient individual variability and long-term stability, akin to humpback whale flukes (Arnold et al., 2005; Sobtzick, 2010). Due to their interactions with tourists and the growing popularity of underwater photography, there is a significant "citizen science" component to this 
photo-identification programme, to which tens of thousands of images are now contributed each winter season (Sobtzick, 2010; Birtles et al., 2014). Mark-recapture modeling has provided an estimate of the "interacting population" (noting an unknown proportion of whales that do not interact voluntarily with vessels and swimmers) over three seasons, consisting of several hundred animals each year (Sobtzick, 2010). Due to an increasing quantity of images collected annually, the manual image matching process is not cost-effective for some larger populations, and new pattern recognition algorithms may provide a solution to this problem. Konovalov et al. (2018) report on a "proof of concept" for recognizing individual dwarf minke whales using the Deep Learning Convolutional Neural Networks tool. Further advancements in the use of such technology may lead to a viable alternative to manual photo analysis in the near future.

\section{Satellite Tags, Multisensor Tags, and Unmanned Aerial Systems (UAS)}

Technological advances are improving our ability to measure and understand the biology of minke whales around the world. Although not necessarily novel, satellite telemetry is a key tool for collecting data that improves our understanding of the broadscale movement patterns, behaviors, and associations between individuals and their environment over times that are relevant to the biology of the species. Information from satellite tags can provide insights on critical and preferred habitats. From foraging to migration, satellite tags offer a unique perspective on minke whales over extended spatio-temporal ranges that cannot be easily obtained using other methods (Birtles et al., 2015; Víkingsson and Heide-Jørgensen, 2015).

The advent of smaller multi-sensor recording tags has revolutionized our ability to quantify and provide detailed information on the underwater behavior of diving animals. For example, researchers are now able to observe and measure the feeding rates of minke whales (e.g., Friedlaender et al., 2014). These motion-sensing tags (which can also include pointof-view video) allow for unprecedented measurement of the kinematics, speed, maneuverability, energy expenditure, and even information on the habitat of diving animals (Friedlaender et al., 2009, 2014, 2016; Goldbogen et al., 2015, 2017; Cade et al., 2016). The ability to measure the fine-scale movement and behavior of minke whales is critical to providing quantitative information on their energetic needs, daily behavior, and potential for being impacted by environmental change.

Unmanned aerial systems (UAS) are an emerging technology that can be used in a number of different capacities to collect valuable information on minke whales and their habitats. UAS have been shown to be able to accurately measure not only the total length of individual marine mammals, but also their general health condition (Christiansen et al., 2016; Durban et al., 2016). This information is critical to being able to extrapolate to the population-level regarding the age-class distribution, individual health measures, and overall fitness of a population. UAS are also being used to collect expired breaths from marine mammals that can be chemically evaluated to measure hormone levels and even extract DNA (Pirotta et al., 2017). This information is useful for determining stress and pregnancy as well as the population of which an individual is a part. UAS can also be used to survey smaller areas at high-resolution with accurate geo-referencing. This information is critical when linking the small-scale movement patterns and behavior of animals to their environment as such surveys can provide insights as to the amount of available habitat in an area.

\section{Passive Acoustic Monitoring (PAM)}

Minke whales are known to produce a variety of sounds across their geographic range. In the North Atlantic, frequencymodulated downsweeps and low-frequency pulse trains with varying inter-pulse interval structure have been attributed to minke whales (Beamish and Mitchell, 1973; Edds-Walton, 2000; Mellinger et al., 2000). In the early 2000s, the North Pacific "boing" sound was identified as a minke whale call (Rankin and Barlow, 2005), and more recently low-frequency downsweep and pulse-train sounds were described from recordings made in British Columbia, Canada (Nikolich and Towers, 2018). Australian dwarf minke whales produce a complex call, dubbed the "star wars" vocalization (Gedamke et al., 2001; Figures 2A-C). In the southern hemisphere, the "bioduck signal" (Figures 2D,E), which had been recorded in the Southern Ocean for decades, has recently been attributed to the Antarctic minke whale (Risch et al., 2014b).

As mentioned above, visual surveys for marine mammals are carried out mostly during daylight and summer months, leaving large data gaps for many species' winter distribution and daily habitat use. Long-term PAM surveys have been shown to be capable in filling some of these gaps and are particularly useful for the study of cryptic species that are difficult to detect visually, such as minke whales (e.g., Risch et al., 2019). Recent advances in digital signal acquisition and processing, increased storage capacity, and reduced power consumption and instrument size means that PAM is increasingly complementing visual surveys of marine mammals (Clark et al., 2010; Gerrodette et al., 2011). Towed hydrophone arrays are now commonly used on marine mammal surveys, and in some cases, the passive acoustic data collected have been used for estimates of relative abundance of minke whales (Barlow and Taylor, 2005; Norris et al., 2017). Large-scale networks of bottommounted hydrophones and autonomous acoustic recorders have been used to investigate migratory routes, changes in distribution and to describe previously unknown habitats of baleen whales (Clark and Gagnon, 2004; Risch et al., 2014a; Davis et al., 2017). Time-synchronized hydrophone arrays are now being used in semi-automated approaches to localize and even track individual animals (Martin et al., 2017). Where detailed knowledge on the vocal behavior (e.g., calling or cue rate) of the target population exists, PAM can be used to estimate densities of animals (Lewis et al., 2007; Efford et al., 2009; Marques et al., 2013; Harris et al., 2018). For example, passive acoustic data has been used to estimate relative abundance of North Pacific minke whales in a small area using their "boing" vocalizations and applying cue-counting 
A

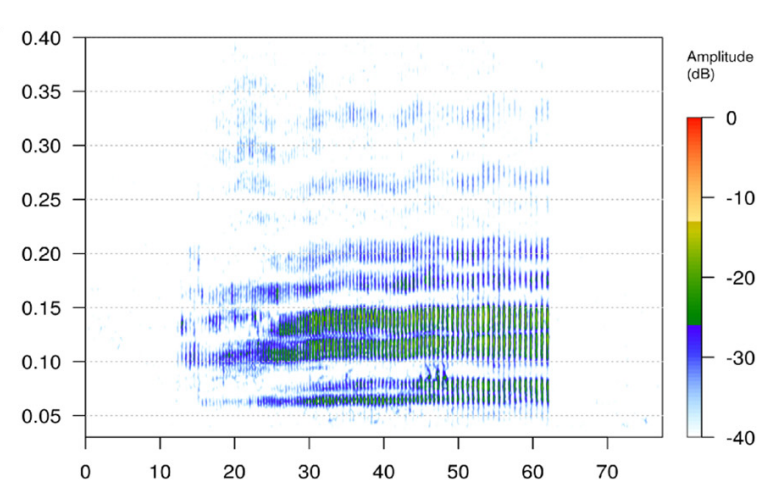

C

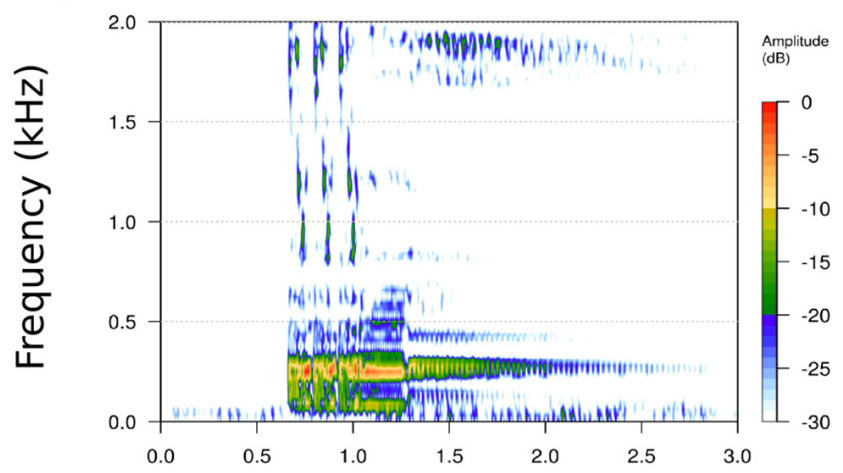

E

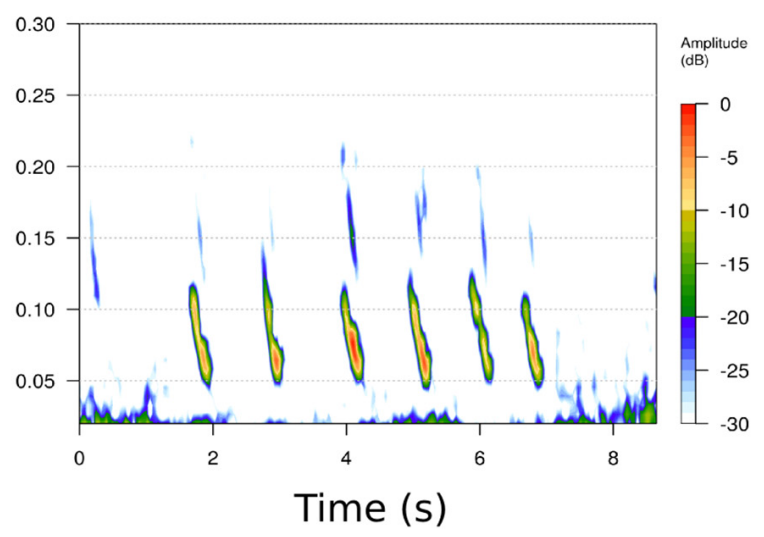

B

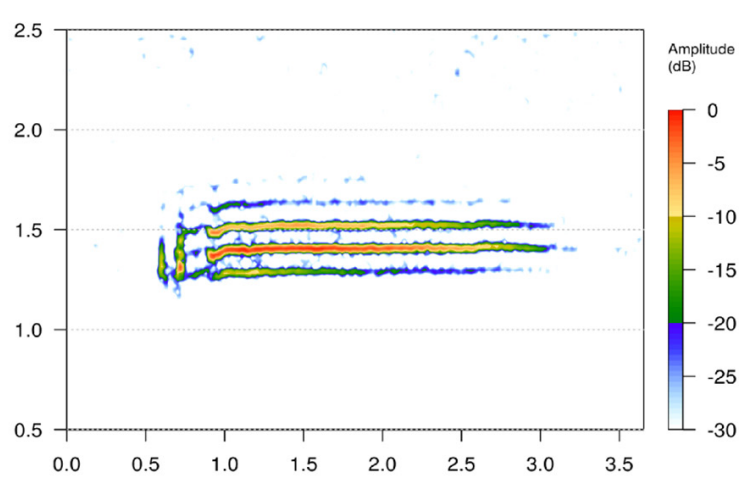

D

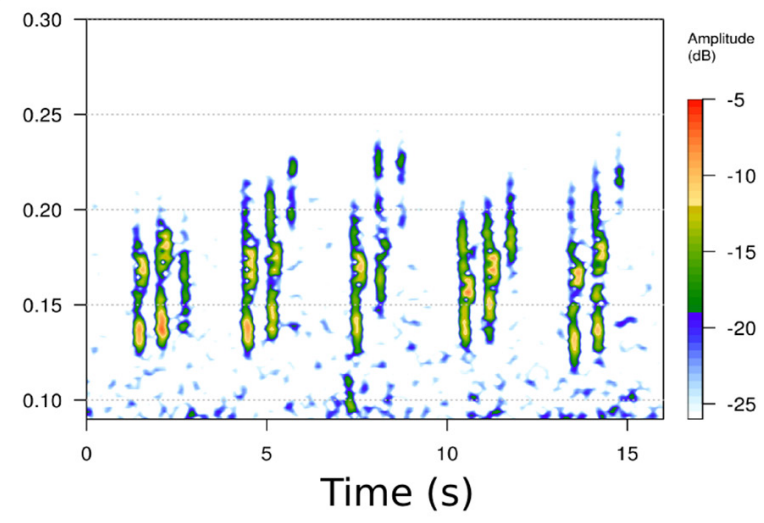

FIGURE 2 | Spectrograms of known minke whale vocalizations from different oceanbasins. (A) North Atlantic slow-down pulse trains, (B) North Pacific "boing" vocalization, (C) Australian dwarf minke whale "star wars" vocalization, (D) Antactic "bioduck," (E) Antarctic downsweeps. Note different time and frequency scales. Spectrogramparameters: (A) Fast Fourier Transform (FFT) $=1024$ pt, overlap (ovlp) $=75 \%$, samplerate $(\mathrm{SR})=2000 \mathrm{~Hz}$ : frequency resolution (FR) $=1.9 \mathrm{~Hz}$, time resolution (TR) = $128 \mathrm{~ms}$; (B) FFT $=512 \mathrm{pt}$, ovlp $=75 \%, \mathrm{SR}=8000 \mathrm{~Hz}$ : FR $=15.6 \mathrm{~Hz}, \mathrm{TR}=16 \mathrm{~ms}$; (C) FFT $=512 \mathrm{pt}$, ovlp $=75 \%, \mathrm{SR}=16,000 \mathrm{~Hz}$ : FR $=31.5 \mathrm{~Hz}$, $\mathrm{TR}=8 \mathrm{~ms}$; (D) $\mathrm{FFT}=1024 \mathrm{pt}$, ovlp $=75 \%, \mathrm{SR}=4000 \mathrm{~Hz}$ : FR= $3.9 \mathrm{~Hz}$, TR= $64 \mathrm{~ms}$; (E) FFT = $4096 \mathrm{pt}$, ovlp $=75 \%, \mathrm{SR}=25,811 \mathrm{~Hz}: \mathrm{FR}=6.3 \mathrm{~Hz}, \mathrm{TR}=39 \mathrm{~ms}$.

methods using the calling rate from a single tracked individual (Martin et al., 2013).

The recent development of these new statistical methods for density estimation based on PAM data show great promise for monitoring minke whales in challenging offshore, remote, and sometimes ice-covered habitats. However, several assumptions must be met and parameters, such as cue rates, need to be known in order to reliably estimate animal abundance from passive acoustic data (Marques et al., 2013). However, the vocalization rate for most marine mammals, including minke whales can be quite variable (Oleson et al., 2007; Parks et al., 2011b), making it difficult to estimate accurate and robust cue rates. Techniques to overcome these challenges include collecting data using acoustic tags and behavioral focal follow studies (Johnson et al., 2009; Parks et al., 2011a).

In addition to monitoring population abundance, PAM data can be used for exploring geographic variability in vocalizations with the potential to reveal population structure (Rankin and 
Barlow, 2005; McDonald et al., 2006b), migration routes (Norris et al., 1995; Risch et al., 2014a), habitat use and environmental correlates (Baumgartner and Fratantoni, 2008; Stafford et al., 2009) as well as for the study of behavior and the impact of anthropogenic activities (Forney et al., 2017).

\section{CONSERVATION STATUS AND MANAGEMENT APPROACHES}

Although abundance estimates are missing for large parts of their known distributional range, common minke whales are currently listed as a species of Least Concern (LC) under the International Union for Conservation of Nature (IUCN) Red List (Cooke et al., 2018a). The Convention on International Trade in Endangered Species (CITES) lists all common minke whale populations under Appendix I (threatened with extinction), with the exception of the West Greenland stock, which is listed under Appendix II (not currently threatened but trade needs to be strictly regulated).

Latest best estimates by the International Whaling Commission (IWC) are 90,000 (CI $=60,000-130,000)$ for the eastern North Atlantic; 50,000 (CI = 30,000-85,000) for the central Atlantic, and 17,000 (7,000-40,000) for West Greenland ${ }^{3}$. The most recent abundance estimate for the Canadian East coast stock is 2,591 $(\mathrm{CV}=0.81)$ animals (Hayes et al., 2018). It has been suggested, that there may be two separate breeding populations in the North Atlantic (Anderwald et al., 2011), but no definite breeding grounds have yet been confirmed. Other studies have found no evidence for population structuring in the North East Atlantic but highlighted the importance of analysis of more genetic markers to answer the question conclusively (Quintela et al., 2014).

The North Pacific has generally been surveyed less and population estimates are thus patchy. The most recent analysis of inshore ship line transect surveys from the US west coast (Washington to California) estimated $636(\mathrm{CV}=0.72)$ animals (Carretta et al., 2017). A passive acoustic line-transect survey of the Northern Mariana Islands estimated between 80 and 91 animals $(\mathrm{CV}=0.34)$ for this area in winter and spring (Norris et al., 2017). Because acoustic estimates are based on vocalizations believed to be produced only by males, these are considered minimum estimates. The latest IWC "best" estimate for the western North Pacific and Okhotsk Sea is 22,000 (CI under review) animals ${ }^{3}$. At least two sub-populations are currently recognized in the western North Pacific, although acoustic records suggest that further population structure might exist (Rankin and Barlow, 2005). While the sub-population called "J stock" inhabits the Yellow Sea, East China Sea and the Sea of Japan, "O stock" inhabits more offshore waters of the Northwest Pacific and the Okhotsk Sea (Kato, 1992). There has been serious concern and debate within the IWC about the status of J stock, which in addition to being targeted by whaling operations, is also frequently caught incidentally in fishing gear (Song, 2016; Cooke et al., 2018a). The current

${ }^{3}$ https://iwc.int/home (accessed March 29, 2019). minimum population estimate for this population is 5,247 animals (Song, 2016).

The abundance of dwarf minke whales in the Southern Ocean has not been assessed systematically, because in the past most sighting surveys and whaling records did not distinguish it from the Antarctic minke whale (Cooke et al., 2018a). For example, the IWC sightings surveys carried out in the Southern Ocean (IDCR-SOWER) identified only a small percentage of minke whale sightings as dwarf minke whale (Branch and Butterworth, 2001). To our knowledge, the only abundance estimate of a dwarf minke whale population to date is from the Great Barrier Reef, where photo-ID data collected over 3 years suggested a yearly fluctuating "interacting population" size of between 342 and 789 individuals (Sobtzick, 2010).

The most recent estimate of overall abundance of Antarctic minke whales is around 500,000 individuals, down from an estimated 720,000 in earlier assessments (International Whaling Commission, 2013). Notwithstanding a lack of confidence in parts of this assessment, this represents a $31 \%$ decline, the direction and reasons of which currently are unknown. There is also disagreement as to whether current abundance estimates are similar to pre-whaling abundance figures. One of the difficulties in generating abundance estimates for this species is due to its affinity for sea ice, as has been shown by recent aerial surveys (Williams et al., 2014; Herr et al., 2019). Despite these logistical challenges and ongoing discussions, current population estimates and their trajectory give reason for concern and accordingly have resulted in the recent classification of Antarctic minke whales as Near Threatened under the IUCN Red List and under Appendix I of CITES (Cooke et al., 2018b).

Combining the effects of various anthropogenic pressures on individuals and populations and addressing them in a cumulative context still presents a considerable challenge, in urgent need of new scientific and conservation approaches (Côté et al., 2016). This is especially true for highly mobile species and when disturbances change over space and time. Several frameworks such as the Population Consequences of Disturbance (PCoD) model (Pirotta et al., 2018) have been developed in recent years. These models attempt to link health effects of combined pressures with vital rates that can be scaled up to population consequences but are still often limited by our ability to accurately parameterize parts of the model and deal with uncertainties. While new research and innovations in methods, tools and techniques are needed to address the many outstanding information deficiencies, long-term monitoring of populations and the pressures to which they are exposed, provides vital feedback on the effectiveness of management policies and actions. Such monitoring must be integrative, encompassing not only abundance estimates of the whales, but also components of the wider system in which they live, including natural and anthropogenic pressures. In practice, these types of monitoring programmes and adaptive management approaches are scarce. However, an example of such a programme has recently been applied in the Great Barrier Reef, which uses the Driver, Pressure, State, Impact, and Response (DPSIR) framework to identify and connect appropriate indicators for monitoring and enhancing the system-wide understanding 


\section{Dwarf Minke Whales of the GBR}

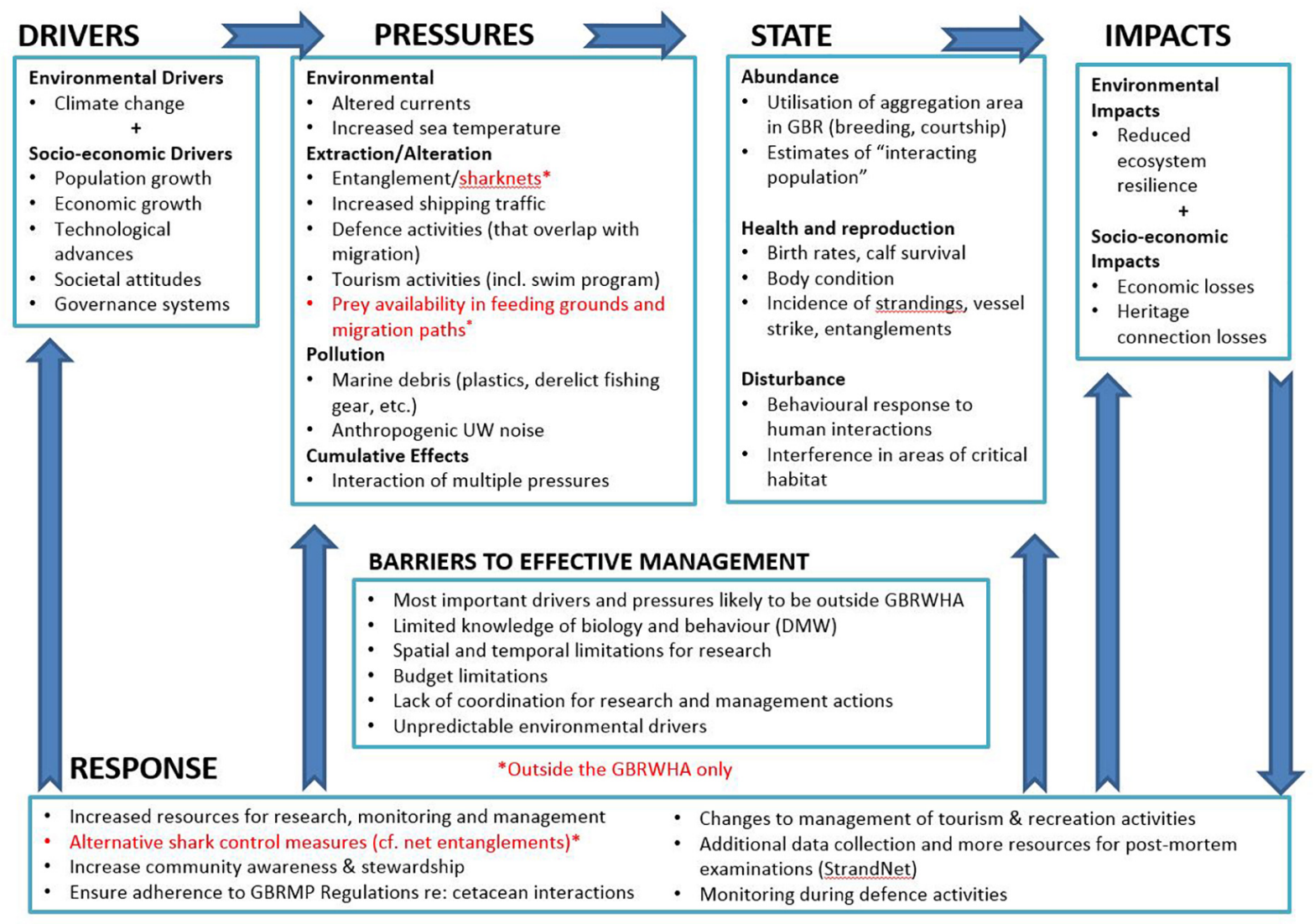

FIGURE 3 | Example Driver, Pressure, State, Impact, and Response (DPSIR) flowchart identifying system components and relationships relevant to integrated monitoring of dwarf minke whales in the Great Barrier Reef World Heritage Area (adapted from Curnock et al., 2018, for illustrative purposes).

(Great Barrier Reef Marine Park Authority, 2015). Developed in the late 1990s by the European Environmental Agency (EEA), DPSIR provides an integrative model for monitoring and assessment of linked social-ecological systems at multiple scales (Gari et al., 2015). Within DPSIR, Drivers are the overarching causes and trends that influence a range of events/activities that exert Pressures on parts of the system (e.g., climate change influences storm intensity, and coastal development influences ocean pollution). State represents the condition of a value (e.g., a characteristic of a whale population, such as abundance, health, reproduction, etc.) that can/will respond to pressures and change over time, whereas Impact is considered to be the resultant effect to human well-being that flows from a change in the state of a value (e.g., a loss of cultural, economic or heritage value associated with a whale population). Responses are actions taken by resource managers and/or communities to influence drivers, mitigate pressures and/or restore the state of values (Carr et al., 2007; Tscherning et al., 2012; Gari et al., 2015). The development of an integrated monitoring programme for the Great Barrier Reef utilizes DPSIR to identify relationships and processes between system components (e.g., whales and shipping, agriculture and corals, etc.) assisting with identification of knowledge gaps, barriers to effective management and the prioritization of monitoring effort (see Figure 3).

\section{CONCLUSION: DATA GAPS, RESEARCH, AND MONITORING PRIORITIES}

The expansive, seasonally changing distribution patterns of many minke whale populations, means that they are exposed to a number of anthropogenic threats throughout their range. Pressures vary in type and severity in different habitats and are often cumulative, making it difficult to protect such highly mobile populations, especially when large parts of their year-round distribution are unknown.

A priority for future research should therefore be to better understand migratory routes and seasonal habitats, in particular winter breeding grounds, of minke whale populations worldwide. Such efforts should focus on populations that are currently commercially exploited or threatened, like those in the Northwest Pacific, and those that are currently not being monitored, such as almost all populations of dwarf minke whales. In the case of Antarctic minke whales it is important to better understand their 
in-ice distribution and its effects on current population estimates. Dedicated and opportunistic PAM networks are recommended to define migration corridors, identify currently unknown offshore habitats and monitor longer-term changes in distribution (see Davis et al., 2017). In this context, a better understanding of the full vocal repertoire, especially behavioral and density dependent variability in calling rates will also be important.

Both common minke whales in the Arctic and Antarctic minke whales show sexual segregated migration with females generally moving toward higher latitudes (Horwood, 1990; Laidre et al., 2009). A better understanding of such behavior is important for species monitoring and assessing impacts of ongoing whaling operations. Non-lethal new technologies such as PAM, UAS, multi-sensor and satellite tags can help to address such knowledge gaps even in challenging remote and offshore habitats.

Entanglements in fishing gear and ship strike are affecting baleen whale populations worldwide, but the extent of these impacts and how they relate to other pressures are rarely fully

\section{REFERENCES}

Acevedo, J., Aguayo-Lobo, A., Acuna, P., and Pastene, L. (2006). A note on the first record of the dwarf minke whale (Balaenoptera acutorostrata) in Chilean waters. J. Cetacean Res. Manag. 8, 293-296.

Acevedo, J., Olavarría, C., Plana, J., Aguayo-Lobo, A., Larrea, A., and Pastene, L. A. (2011). Occurrence of dwarf minke whales (Balaenoptera acutorostrata subsp.) around the Antarctic Peninsula. Polar Biol. 34, 313-318. doi: 10.1007/s00300010-0884-y

Aguilar, A., Grau, E., Sanpera, C., Jover, L., and Donovan, G. (1983). Report of the "Ballena 1" whale marking and sighting cruise in the waters off western Spain. Rep. Int. Whaling Comm. 33, 649-655.

Anderwald, P., Daníelsdóttir, A. K., Haug, T., Larsen, F., Lesage, V., Reid, R. J., et al. (2011). Possible cryptic stock structure for minke whales in the North Atlantic: implications for conservation and management. Biol. Conserv. 144, 2479-2489. doi: 10.1016/j.biocon.2011.07.002

Andrew, R. K., Howe, B. M., Mercer, J. A., and Dzieciuch, M. A. (2002). Ocean ambient sound: comparing the 1960s with the 1990s for a receiver off the California coast. Acoust. Res. Lett. Online 3, 65-70. doi: 10.1121/1.1461915

Arnold, P., Birtles, A., Dunstan, A., and Lukoschek, M. V. (2005). Colour patterns of the dwarf minke whale Balaenoptera Acutorostrata sensu lato: description, cladistic analysis and taxonomic implications. Mem. Queensl. Museum 51, 277-307.

Arnold, P. W. (1997). Occurrence of dwarf minke whales (Balaenoptera acutorostrata) on the northern great barrier reef, Australia. Rep. Int. Whaling Comm. 47, 419-424.

Arnold, P. W., and Birtles, A. (1999). Towards Sustainable Management of the Developing Dwarf Minke Whale Tourism Industry in Northern Queensland. Townsville: CRC Reef Research Centre Townsville.

Atkinson, A., Siegel, V., Pakhomov, E., and Rothery, P. (2004). Long-term decline in krill stock and increase in salps within the Southern Ocean. Nature 432, 100-103. doi: 10.1038/nature02996

Baker, C. S., and Clapham, P. (2004). Modelling the past and future of whales and whaling. Trends Ecol. Evol. 19, 365-371. doi: 10.1016/j.tree.2004.05.005

Baker, C. S., Lento, G. M., Cipriano, F., Dalebout, M. L., and Palumbi, S. R. (2000). Scientific whaling: source of illegal products for market? Science 290, 1695-1696.

Baker, C. S., Steel, D., Choi, Y., Lee, H., Kim, K. S., Choi, S. K., et al. (2010). Genetic evidence of illegal trade in protected whales links Japan with the US and South Korea. Biol. Lett. 6, 647-650. doi: 10.1098/rsbl.2010. 0239

Balcomb, K., and Claridge, D. E. (2001). A mass stranding of cetaceans caused by naval sonar in the Bahamas. Bahams J. Sci. 3, 2-12. understood. The case of the J-stock population of common minke whales in the Northwest Pacific is an example of interactions of pressures putting a small population at risk for survival. Japan's announced withdrawal from the IWC in December 2018 potentially places even more pressure on this endangered (and other) populations in their EEZ.

Finally, climate change and its effects on global oceanic ecosystems are changing environmental and anthropogenic pressures that determine migratory routes and species habitats at an increasingly faster pace (Tulloch Ayesha et al., 2019), requiring flexible and adaptable conservation approaches. Across species, comparative and multi-disciplinary approaches are thus necessary to conserve minke whale populations worldwide.

\section{AUTHOR CONTRIBUTIONS}

DR coordinated this work. All authors (DR, MC, TN, and AF) contributed to writing and editing the work.

Barlow, J. (2015). Inferring trackline detection probabilities, $g(0)$, for cetaceans from apparent densities in different survey conditions. Mar. Mammal Sci. 31, 923-943. doi: $10.1111 / \mathrm{mms} .12205$

Barlow, J., and Taylor, B. L. (2005). Estimates of sperm whale abundance in the northeastern temperate Pacific from a combined acoustic and visual survey. Mar. Mammal Sci. 21, 429-445. doi: 10.1111/j.1748-7692.2005.tb 01242.x

Baulch, S., and Perry, C. (2014). Evaluating the impacts of marine debris on cetaceans. Mar. Pollut. Bull. 80, 210-221. doi: 10.1016/j.marpolbul.2013. 12.050

Baumgartner, M. F., and Fratantoni, D. M. (2008). Diel periodicity in both sei whale vocalization rates and the vertical migration of their copepod prey observed from ocean gliders. Limnol. Oceanogr. 53, 2197-2209. doi: 10.4319/lo.2008.53. 5_part_2.2197

Beamish, P., and Mitchell, E. (1973). Short pulse length audio frequency sounds recorded in the presence of a Minke whale (Balaenoptera acutorostrata). Deep Sea Res. Oceanogr. Abstr. 20, 375-380. doi: 10.1016/0011-7471(73)90060-0

Bejder, L., Samuels, A., Whitehead, H., Gales, N., Mann, J., Connor, R., et al. (2006). Decline in relative abundance of bottlenose dolphins exposed to longterm disturbance. Conserv. Biol. 20, 1791-1798. doi: 10.1111/j.1523-1739.2006. 00540.x

Best, B. D., Halpin, P. N., Read, A. J., Fujioka, E., Good, C. P., LaBrecque, E. A., et al. (2012). Online cetacean habitat modeling system for the US east coast and Gulf of Mexico. Endanger. Species Res. 18, 1-15. doi: 10.3354/esr00430

Best, P. B. (1982). Seasonal aboundance, feeding, reproduction, age and growth in minke whales off Durban (with incidental observations from the Antarctic). Rep. Int. Whaling Comm. 32, 759-786.

Best, P. B. (1985). External characters of southern minke whales and the existence of a diminutive form. Sci. Rep. Whales Res. Inst. 36, 1-33.

Birtles, A., Andrews, D. R., and Jenner, C. (2015). Spatial Ecology, Migratory Paths and Critical Areas of Habitat use of Australia's Dwarf Minke Whales. Preliminary Report on 2013/36. Townsville: Australian Marine Mammal Centre.

Birtles, A., Valentine, P., Curnock, M., Mangott, A., Sobtzick, S., and Marsh, H. (2014). Report to the Great Barrier Reef Marine Park Authority on the Dwarf Minke Whale Tourism Monitoring Program (2003-2008). Research Publication 112. Townsville: Great Barrier Reef Marine Park Authority.

Borchers, D. L., Zucchini, W., Heide-Jørgensen, M. P., Cañadas, A., and Langrock, R. (2013). Using hidden markov models to deal with availability bias on line transect surveys. Biometrics 69, 703-713. doi: 10.1111/biom.12049

Branch, T. A., and Butterworth, D. S. (2001). Estimates of abundance south of $60^{\circ} \mathrm{S}$ for cetacean species sighted frequently on the $1978 / 79$ to 1997/98 IWC/IDCR-SOWER sighting surveys. J. Cetacean Res. Manag. 3, 251-270. 
Brierley, A. S., and Clapham, P. J. (2016). Whaling permits: japan's whaling is unscientific. Nature 529:283. doi: 10.1038/529283a

Cade, D. E., Friedlaender, A. S., Calambokidis, J., and Goldbogen, J. A. (2016). Kinematic diversity in rorqual whale feeding mechanisms. Curr. Biol. 26, 2617-2624. doi: 10.1016/j.cub.2016.07.037

Carr, E. R., Wingard, P. M., Yorty, S. C., Thompson, M. C., Jensen, N. K., and Roberson, J. (2007). Applying DPSIR to sustainable development. Int. J. Sustain. Dev. World Ecol. 14, 543-555. doi: 10.1007/s10661-014-4225-4

Carretta, J. V., Forney, K. A., Oleson, E., Weller, D. W., Lang, A., Baker, J., et al. (2017). US Pacific Marine Mammal Stock Assessments: 2016. NOAA Technical Memorandum. La Jolla, CA: National Oceanic and Atmospheric Administration.

Cassoff, R., Moore, K., McLellan, W., Barco, S., Rotstein, D., and Moore, M. (2011). Lethal entanglement in baleen whales. Dis. Aquat. Organ. 96, 175-185. doi: 10.3354/dao02385

Cates, K., DeMaster, D. P., Brownell, R. L. J., Silber, G., Gende, S., and Leaper, R. (2017). Strategic Plan to Mitigate the Impacts of Ship Strikes on Cetacean Populations: 2017-2020. Paper IWC/66/CC20 Presented to the International Whaling Commission Scientific Committee, Bled, 19.

Cerchio, S., Rasoloarijao, T., and Cholewiak, D. (2018). Acoustic monitoring of Blue Whales (Balaenoptera musculus) and other baleen whales in the Mozambique Channel off the Northwest Coast of Madagascar. Paper SC/67B/SH/14 Presented to the International Whaling Commission Scientific Committee, Bled, 13.

Cholewiak, D., Clark, C. W., Ponirakis, D., Frankel, A., Hatch, L. T., Risch, D., et al. (2018). Communicating amidst the noise: modeling the aggregate influence of ambient and vessel noise on baleen whale communication space in a national marine sanctuary. Endanger. Species Res. 36, 59-75. doi: 10.3354/esr00875

Christiansen, F., Dujon, A. M., Sprogis, K. R., Arnould, J. P. Y., and Bejder, L. (2016). Noninvasive unmanned aerial vehicle provides estimates of the energetic cost of reproduction in humpback whales. Ecosphere 7:e01468. doi: $10.1002 /$ ecs 2.1468

Christiansen, F., Rasmussen, M. H., and Lusseau, D. (2014). Inferring energy expenditure from respiration rates in minke whales to measure the effects of whale watching boat interactions. J. Exp. Mar. Biol. Ecol. 459, 96-104. doi: 10.1016/j.jembe.2014.05.014

Clapham, P. J. (2017). Whaling permits: japan disregards whaling review again. Nature 547:32. doi: 10.1038/547032b

Clark, C. W., Brown, M., and Corkeron, P. (2010). Visual and acoustic surveys for North Atlantic right whales, Eubalaena glacialis, in Cape Cod Bay, Massachusetts, 2001-2005: management implications. Mar. Mammal Sci. 26, 837-854. doi: $10.1111 / j .1748-7692.2010 .00376 . x$

Clark, C. W., and Gagnon, G. J. (2004). Low-frequency vocal behaviors of baleen whales in the north atlantic: insights from integrated undersea surveillance system detections, locations, and tracking from 1992 to 1996. US Navy J. Underw. Acoust. 52, 609-640.

Cooke, J. G., Zerbini, A. N., and Taylor, B. (2018a). Balaenoptera Acutorostrata. IUCN Red List Threat. Species 2018 e.T2480A50350661. Available at: http:// www.iucnredlist.org (accessed May 5, 2019).

Cooke, J. G., Zerbini, A. N., and Taylor, B. (2018b). Balaenoptera Bonaerensis. IUCN Red List Threat. Species 2018 e.T2480A50350661. Available at: http:// www.iucnredlist.org (accessed May 5, 2019).

Côté, I. M., Darling, E. S., and Brown, C. J. (2016). Interactions among ecosystem stressors and their importance in conservation. Proc. R. Soc. Lond. 283:20152592. doi: 10.1098/rspb.2015.2592

Curnock, M., Williams, G., Noad, M., Smith, J., West, L., Birtles, A., et al., (2018). Great whales in the Great Barrier Reef: Review and proposal for monitoring in RIMReP. Report to the Great Barrier Reef Marine Park Authority and Australian Institute of Marine Science, Townsville.

Curnock, M. I., Birtles, R. A., and Valentine, P. S. (2013). Increased use levels, effort, and spatial distribution of tourists swimming with dwarf minke whales at the Great Barrier Reef. Tour. Mar. Environ. 9, 5-17. doi: 10.3727/ $154427313 \times 13659574649867$

Davis, G. E., Baumgartner, M. F., Bonnell, J. M., Bell, J., Berchok, C., Thornton, J. B., et al. (2017). Long-term passive acoustic recordings track the changing distribution of North Atlantic right whales (Eubalaena glacialis) from 2004 to 2014. Sci. Rep. 7, 13460-13472. doi: 10.1038/s41598-017-13359-3

Dawson, S. M., and Slooten, E. (1990). Stranding of a dwarf minke whale at banks Peninsula, New Zealand. New Zeal. Nat. Sci. 17, 89-93.
De Boer, M. N. (2015). Cetaceans observed in suriname and adjacent waters. Lat. Am. J. Aquat. Mamm. 10, 2-19.

Dolman, S. J., and Brakes, P. (2018). Sustainable fisheries management and the welfare of bycaught and entangled cetaceans. Front. Vet. Sci. 5:287. doi: 10.3389/ fvets.2018.00287

Dolman, S. J., and Moore, M. J. (2017). "Welfare implications of cetacean bycatch and entanglements," in Marine Mammal Welfare, ed. A. Butterworth (Berlin: Springer), 41-65. doi: 10.1007/978-3-319-46994-2_4

Dominello, T., and Široviæ, A. (2016). Seasonality of antarctic minke whale (Balaenoptera bonaerensis) calls off the western Antarctic Peninsula. Mar. Mamm. Sci. 32, 826-838. doi: 10.1111/mms. 12302

Doniol-Valcroze, T., Berteaux, D., Larouche, P., and Sears, R. (2007). Influence of thermal fronts on habitat selection by four rorqual whale species in the Gulf of St. Lawrence. Mar. Ecol. Prog. Ser. 335, 207-216. doi: 10.3354/meps33 5207

Dorsey, E. M. (1983). Exclusive adjoining ranges in individually identified minke whales (Balaenoptera acutorostrata) in Washington state. Can. J. Zool. 61, 174-181. doi: 10.1139/z83-022

Dorsey, E. M., Stern, S. J., Hoelzel, A. R., and Jacobsen, J. (1990). Minke whales (Balaenoptera acutorostrata) from the West Coast of North America: individual recognition and small-scale site fidelity. Rep. Int. Whaling Comm. 12, 357-368.

Ducklow, H., Clarke, A., Dickhut, R., Doney, S. C., Geisz, H., Huang, K., et al. (2012). "The marine system of the Western Antarctic Peninsula," in Antarctic Ecosystems: An Extreme Environment in a Changing World, eds A. D. Rogers, N. M. Johnston, E. J. Murphy, and A. Clarke (Hoboken, NJ: Blackwell Publishing Ltd), 121-159.

Durban, J. W., Moore, M. J., Chiang, G., Hickmott, L. S., Bocconcelli, A., Howes, G., et al. (2016). Photogrammetry of blue whales with an unmanned hexacopter. Mar. Mamm. Sci. 32, 1510-1515. doi: 10.1111/mms.12328

Edds-Walton, P. L. (2000). Vocalizations of menke whales Balaenoptera acutorostrata in the St. Lawrence Estuary. Bioacoustics 11, 31-50. doi: 10.1080/ 09524622.2000 .9753448

Efford, M. G., Dawson, D. K., and Borchers, D. L. (2009). Population density estimated from locations of individuals on a passive detector array. Ecology 90, 2676-2682. doi: 10.1890/08-1735.1

Elfes, C. T., VanBlaricom, G. R., Boyd, D., Calambokidis, J., Clapham, P. J., Pearce, R. W., et al. (2010). Geographic variation of persistent organic pollutant levels in humpback whale (Megaptera novaeangliae) feeding areas of the North Pacific and North Atlantic. Environ. Toxicol. Chem. 29, 824-834. doi: 10.1002/etc.110

Erbe, C. (2002). Underwater noise of whale-watching boats and potential effects on killer whales (Orcinus orca), based on an acoustic impact model. Mar. Mamm. Sci. 18, 394-418. doi: 10.1111/j.1748-7692.2002.tb01045.x

Ferguson, M. C., Angliss, R. P., Kennedy, A., Lynch, B., Willoughby, A., Helker, V., et al. (2018). Performance of manned and unmanned aerial surveys to collect visual data and imagery for estimating arctic cetacean density and associated uncertainty. J. Unmanned Veh. Syst. 6, 128-154. doi: 10.1139/juvs-2018-0002

Forney, K. A., Southall, B. L., Slooten, E., Dawson, S., Read, A. J., Baird, R. W., et al. (2017). Nowhere to go: noise impact assessments for marine mammal populations with high site fidelity. Endanger. Species Res. 32, 391-413. doi: $10.3354 /$ esro0820

Fraser, W. R., and Hofmann, E. E. (2003). A predator1s perspective on causal links between climate change, physical forcing and ecosystem response. Mar. Ecol. Prog. Ser. 265, 1-15. doi: 10.3354/meps265001

Fraser, W. R., Trivelpiece, W. Z., Ainley, D. G., and Trivelpiece, S. G. (1992). Increases in Antarctic penguin populations: reduced competition with whales or a loss of sea ice due to environmental warming? Polar Biol. 11, 525-531.

Friedlaender, A. S., Fraser, W. R., Patterson, D., Qian, S. S., and Halpin, P. N. (2008) The effects of prey demography on humpback whale (Megaptera novaeangliae) abundance around Anvers Island, Antarctica. Polar Biol. 31, 1217-1224. doi: 10.1007/s00300-008-0460-x

Friedlaender, A. S., Goldbogen, J. A., Nowacek, D. P., Read, A. J., Johnston, D., and Gales, N. (2014). Feeding rates and under-ice foraging strategies of the smallest lunge filter feeder, the Antarctic minke whale (Balaenoptera bonaerensis). J. Exp. Biol. 217, 2851-2854. doi: 10.1242/jeb.106682

Friedlaender, A. S., Johnston, D. W., Tyson, R. B., Kaltenberg, A., Goldbogen, J. A., Stimpert, A. K., et al. (2016). Multiple-stage decisions in a marine central-place forager. R. Soc. Open Sci. 3:160043. doi: 10.1098/rsos.160043 
Friedlaender, A. S., Lawson, G. L., and Halpin, P. N. (2009). Evidence of resource partitioning between humpback and minke whales around the western Antarctic Peninsula. Mar. Mamm. Sci. 25, 402-415. doi: 10.1111/j.1748-7692. 2008.00263.x

Gales, N. J., Kasuya, T., Clapham, P. J., and Brownell, R. L. (2005). Japan 's whaling plan under scrutiny. Nature 435, 883-884. doi: 10.1038/435883a

Gari, S. R., Newton, A., and Icely, J. D. (2015). A review of the application and evolution of the DPSIR framework with an emphasis on coastal socialecological systems. Ocean Coast. Manag. 103, 63-77. doi: 10.1016/j.ocecoaman. 2014.11.013

Garrigue, C., and Greaves, J. (2001). Cetacean records for the New Caledonia area (south west Pacific Ocean). Micronesia 34, 27-33.

Gedamke, J., Costa, D. P., and Dunstan, A. (2001). Localization and visual verification of a complex minke whale vocalization. J. Acoust. Soc. Am. 109, 3038-3047. doi: 10.1121/1.1371763

Gerrodette, T., Taylor, B. L., Swift, R., Rankin, S., Jaramillo-Legorreta, A. M., and Rojas-Bracho, L. (2011). A combined visual and acoustic estimate of 2008 abundance, and change in abundance since 1997, for the vaquita, Phocoena sinus. Mar. Mamm. Sci. 27, E79-E100.

Gill, A., Fairbairns, B., and Fairbairns, R. (2000). Photo-Identification of the Minke Whale (Balaenoptera acutorostrata) around the Isle of Mull, Scotland. Report to the Hebridean Whale and Dolphin Trust. Available at: http://www.whaledolphintrust.co.uk/cust_images/research\%20publications/ MinkeWhalePhotoID-AlisonGill.pdf (accessed 4 April 2013)

Glover, K. A., Kanda, N., Haug, T., Pastene, L. A., Oien, N., Goto, M., et al. (2010). Migration of Antarctic minke whales to the Arctic. PLoS One 5:e15197. doi: 10.1371/journal.pone.0015197

Goldbogen, J. A., Cade, D. E., Calambokidis, J., Friedlaender, A. S., Potvin, J., Segre, P. S., et al. (2017). How baleen whales feed: the biomechanics of engulfment and filtration. Ann. Rev. Mar. Sci. 9, 367-386. doi: 10.1146/annurev-marine122414-033905

Goldbogen, J. A., Hazen, E. L., Friedlaender, A. S., Calambokidis, J., DeRuiter, S. L., Stimpert, A. K., et al. (2015). Prey density and distribution drive the three-dimensional foraging strategies of the largest filter feeder. Funct. Ecol. 29, 951-961. doi: 10.1111/1365-2435.12395

Great Barrier Reef Marine Park Authority (2015). Reef 2050 Integrated Monitoring and Reporting Strategy. Townsville: Great Barrier Reef Marine Park Authority.

Hall, A. J., McConnell, B. J., Schwacke, L. H., Ylitalo, G. M., Williams, R., and Rowles, T. K. (2018). Predicting the effects of polychlorinated biphenyls on cetacean populations through impacts on immunity and calf survival. Environ. Pollut. 233, 407-418. doi: 10.1016/j.envpol.2017.10.074

Hammond, P. S., Lacey, C., Gilles, A., Viquerat, S., Borjesson, P., Herr, H., et al. (2017). Estimates of Cetacean Abundance in European Atlantic Waters in Summer 2016 from the SCANS-III Aerial and Shipboard Surveys. 39. Available at: https://synergy.st-andrews.ac.uk/scans3/files/2017/04/SCANSIII-\%0Adesign-based-estimates-2017-04-28-final.pdf (accessed May 5, 2019).

Hardesty, B. D., Good, T. P., and Wilcox, C. (2015). Novel methods, new results and science-based solutions to tackle marine debris impacts on wildlife. Ocean Coast. Manag. 115, 4-9. doi: 10.1016/j.ocecoaman.2015.04.004

Harris, D. V., Miksis-Olds, J. L., Vernon, J. A., and Thomas, L. (2018). Fin whale density and distribution estimation using acoustic bearings derived from sparse arrays. J. Acoust. Soc. Am. 143, 2980-2993. doi: 10.1121/1.5031111

Hayes, S. A., Josephson, E., Maze-Foley, K., Rosel, P. E., Byrd, B., Chavez-Rosales, S., et al. (2018). TM 245 US Atlantic and Gulf of Mexico Marine Mammal Stock Assessments - 2017. NOAA Tech Memo NMFS NE-245. Silver Spring, MD: National Oceanic and Atmospheric Administration.

Heide-Jørgensen, M. P., Nordøy, E. S., Øien, N., Folkow, L. P., Kleivane, L., Blix, A. S., et al. (2001). Satellite tracking of minke whales (Balaenoptera acutorostrata) off the coast of northern Norway. J. Cetacean Res. Manag. 3, $175-178$.

Herr, H., Kelly, N., Dorschel, B., Huntemann, M., Kock, K.-H., Lehnert, L. S., et al. (2019). Aerial surveys for Antarctic minke whales (Balaenoptera bonaerensis) reveal sea ice dependent distribution patterns. Ecol. Evol. 1-19. doi: 10.1002/ ece 3.5149

Higdon, J. W., and Ferguson, S. H. (2009). Loss of Arctic sea ice causing punctuated change in sightings of killer whales (Orcinus orca) over the past century. Ecol. Appl. 19, 1365-1375. doi: 10.1890/07-1941.1

Horwood, J. W. (1990). Biology and Exploitation of the Minke Whale. Boca Raton, FL: CRC Press.
International Whaling Commission (2010). "Report of the Workshop on Welfare Issues Associated with the Entanglement of Large Whales," in Report IWC/62/15 Presented to the International Whaling Commission Scientific Committee, Impington, 33.

International Whaling Commission (2013). Reports of the subcommittee on indepth assessments. J. Cetacean Res. Manag. 14, 195-213.

Jambeck, J. R., Geyer, R., Wilcox, C., Siegler, T. R., Perryman, M., Andrady, A., et al. (2015). Plastic waste inputs from land into the ocean. Science 347, 768-771. doi: $10.1126 /$ science. 1260352

Jepson, P. D., and Law, R. J. (2016). Persistent pollutants, persistent threats. Science 352, 1388-1389. doi: 10.1126/science.aaf9075

Johnson, M., Aguilar de Soto, N., and Madsen, P. T. (2009). Studying the behaviour and sensory ecology of marine mammals using acoustic recording tags: a review. Mar. Ecol. Prog. Ser. 395, 55-73. doi: 10.3354/meps08255

Kasamatsu, F., Nishiwaki, S., and Ishikawa, H. (1995). Breeding areas and southbound migrations of southern minke whales Balaenoptera acutorostrata. Mar. Ecol. Prog. Ser. 119, 1-10. doi: 10.3354/meps119001

Kaschner, K., Quick, N. J., Jewell, R., Williams, R., and Harris, C. M. (2012). Global coverage of cetacean line-transect surveys: status quo, data gaps and future challenges. PLoS One 7:e44075. doi: 10.1371/journal.pone.0044075

Kato, H. (1992). Body length, reproduction and stock separation of minke whales off northern Japan. Rep. Int. Whaling Comm. 42, 443-453.

Knowlton, A. R., Robbins, J., Landry, S., McKenna, H. A., Kraus, S. D., and Werner, T. (2016). Implications of fishing rope strength on the severity of large whale entanglements. Conserv. Biol. 30, 318-328. doi: 10.1111/cobi.12590

Konovalov, A., Hillcoat, S., Williams, G., Birtles, A., Gardiner, N., and Curnock, M. I. (2018). Individual minke whale recognition using deep learning convolutional neural networks. J. Geosci. Environ. Prot. 6, 25-36. doi: 10.4236/ gep.2018.65003

Kvadsheim, P. H., DeRuiter, S., Sivle, L. D., Goldbogen, J., Roland-Hansen, R., Miller, P. J. O., et al. (2017). Avoidance responses of minke whales to 1-4 kHz naval sonar. Mar. Pollut. Bull. 121, 60-68. doi: 10.1016/j.marpolbul.2017. 05.037

Lachmuth, C. L., Barrett-Lennard, L. G., Steyn, D. Q., and Milsom, W. K. (2011). Estimation of southern resident killer whale exposure to exhaust emissions from whale-watching vessels and potential adverse health effects and toxicity thresholds. Mar. Pollut. Bull. 62, 792-805. doi: 10.1016/j.marpolbul.2011. 01.002

Laidre, K. L., Heagerty, P. J., Heide-Jørgensen, M. P., Witting, L., and Simon, M. (2009). Sexual segregation of common minke whales (Balaenoptera acutorostrata) in Greenland, and the influence of sea temperature on the sex ratio of catches. ICES J. Mar. Sci. 66, 2253-2266. doi: 10.1093/icesjms/fsp191

Laist, D. W. (1997). "Impacts of marine debris: entanglement of marine life in marine debris including a comprehensive list of species with entanglement and ingestion records," in Marine Debris, Sources, Impacts, and Solutions, eds J. M. Coe and D. B. Rogers (New York, NY: Springer), 99-139. doi: 10.1007/978-14613-8486-1_10

Laist, D. W., Knowlton, A. R., Mead, J. G., Collet, A. S., and Podesta, M. (2001). Collisions between ships and whales. Mar. Mamm. Sci. 17, 35-75. doi: 10.1111/ j.1748-7692.2001.tb00980.x

Lebeuf, M., Measures, L., Noel, M., Raach, M., and Trottier, S. (2014). A twentyone year temporal trend of persistent organic pollutants in St. Lawrence Estuary beluga, Canada. Sci. Total Environ. 485, 377-386. doi: 10.1016/j.scitotenv.2014. 03.097

Lewis, T., Gillespie, D., Lacey, C., Matthews, J., Danbolt, M., Leaper, R., et al. (2007). Sperm whale abundance estimates from acoustic surveys of the Ionian Sea and Straits of Sicily in 2003. J. Mar. Biol. Assoc. 87, 353-357. doi: 10.1017/ s0025315407054896

Lien, J. (1994). Entrapments of large cetaceans in passive inshore fishing gear in Newfoundland and Labrador (1979-1990). Rep. Int. Whaling Comm. 149-157.

Lynas, E. M., and Sylvestre, J. P. (1988). Feeding techniques and foraging strategies of minke whales (Balaenoptera acutorostrata) in the St Lawrence River Estuary. Aquat. Mamm. 14, 21-32.

Macleod, K., Fairbairns, R., Gill, A., Fairbairns, B., Gordon, J., Blair-Myers, C., et al. (2004). Seasonal distribution of minke whales Balaenoptera acutorostrata in relation to physiography and prey off the Isle of Mull. Scotland. Mar. Ecol. Prog. Ser. 277, 263-274. doi: 10.3354/meps277263

Mangott, A. H., Birtles, R. A., and Marsh, H. (2011). Attraction of dwarf minke whales Balaenoptera acutorostrata to vessels and swimmers in the great barrier 
reef world heritage area - the management challenges of an inquisitive whale. J. Ecotourism 10, 64-76. doi: 10.1080/14724041003690468

Marques, T. A., Thomas, L., Martin, S. W., Mellinger, D. K., Ward, J. A., Moretti, D. J., et al. (2013). Estimating animal population density using passive acoustics. Biol. Rev. 88, 287-309. doi: 10.1111/brv.12001

Martin, S. W., Marques, T. A., Thomas, L., Morrissey, R. P., Jarvis, S., DiMarzio, N., et al. (2013). Estimating minke whale (Balaenoptera acutorostrata) boing sound density using passive acoustic sensors. Mar. Mamm. Sci. 29, 142-158. doi: 10.1111/j.1748-7692.2011.00561.x

Martin, S. W., Martin, C. R., Matsuyama, B. M., and Henderson, E. E. (2015). Minke whales (Balaenoptera acutorostrata) respond to navy training. J. Acoust. Soc. Am. 137, 2533-2541. doi: 10.1121/1.4919319

Martin, S. W., Matsuyama, B., Helble, T. A., Martin, C. R., Henderson, E. E., and Alongi, G. C. (2017). Automated passive acoustic detection, classification, localization, and tracking methods applied to recorded data from the Pacific Missile Range Facility, Kauai, Hawaii. J. Acoust. Soc. Am. 142:2588. doi: 10. $1121 / 1.5014478$

McCauley, R. (2004). Western Australian Exercise Area Blue Whale Project: Final Summary Report. CMST Report R2004- 29, Project-350, 1-73.

McDonald, M. A., Hildebrand, J. A., and Wiggins, S. M. (2006a). Increases in deep ocean ambient noise in the Northeast Pacific west of San Nicolas Island, California. J. Acoust. Soc. Am. 120, 711-718. doi: 10.1121/1.2216565

McDonald, M. A., Mesnick, S., and Hildebrand, J. A. (2006b). Biogeographic characterisation of blue whale song worldwide: using song to identify populations. J. Cetacean Res. Manag. 8, 55-65.

McGarry, T., Boisseau, O., Stephenson, S., and Compton, R. (2017). Understanding the Effectiveness of Acoustic Deterrent Devices (ADDs) on Minke Whale (Balaenoptera acutorostrata), a Low Frequency Cetacean. ORJIP Project 4 Report EOR0692. London: The Carbon Trust.

McKenna, M. F., Katz, S. L., Condit, C., and Walbridge, S. (2012). Response of commercial ships to a voluntary speed reduction measure: are voluntary strategies adequate for mitigating ship-strike risk? Coast. Manag. 40, 634-650. doi: 10.1080/08920753.2012.727749

Meager, J. J. (2016). Marine wildlife stranding and mortality database annual report 2013-2015. Cetacean and Pinniped. Conserv. Tech. Data Rep. 2016, 1-33.

Mellinger, D. K., Carson, C. D., and Clark, C. W. (2000). Characteristics of minke whale (Balaenoptera acutorostrata) pulse trains recorded near Puerto Rico. Mar. Mamm. Sci. 16, 739-756. doi: 10.1111/j.1748-7692.2000.tb00969.x

Miksis-Olds, J. L., Bradley, D. L., and Maggie Niu, X. (2013). Decadal trends in indian ocean ambient sound. J. Acoust. Soc. Am. 134, 3464-3475. doi: 10.1121/ 1.4821537

Mitchell, E. D. (1991). Winter records of the minke whale (Balaenoptera acutorostrata acutorostrata Lacepede 1804) in the southern North Atlantic. Rep. Int. Whaling Comm. 41, 455-457.

Monnahan, C. C., Branch, T. A., and Punt, A. E. (2015). Do ship strikes threaten the recovery of endangered eastern North Pacific blue whales? Mar. Mamm. Sci. 31, 279-297. doi: 10.1111/mms.12157

Moon, H.-B., Kannan, K., Choi, M., Yu, J., Choi, H.-G., An, Y.-R., et al. (2010). Chlorinated and brominated contaminants including PCBs and PBDEs in minke whales and common dolphins from Korean coastal waters. J. Hazard. Mater. 179, 735-741. doi: 10.1016/j.jhazmat.2010.03.063

Moore, M. J., and van der Hoop, J. M. (2012). The painful side of trap and fixed net fisheries: chronic entanglement of large whales. J. Mar. Biol. 2012, 1-4. doi: 10.1155/2012/230653

Morris, E. M., and Vaughan, D. G. (2003). Spatial and temporal variation of surface temperature on the Antarctic Peninsula and the limit of viability of ice shelves. Antarct. Res. Ser. 79, 61-68. doi: 10.1029/ar079p0061

National Marine Fisheries Service (2016). Technical Guidance for Assessing the Effects of Anthropogenic Sound on Marine Mammal Hearing: Underwater Acoustic Thresholds for Onset of Permanent and Temporary Threshold Shifts. Silver Spring, MD: National Oceanic and Atmospheric Administration, 178.

New, L. F., Hall, A. J., Harcourt, R., Kaufman, G., Parsons, E. C. M., Pearson, H. C., et al. (2015). The modelling and assessment of whale-watching impacts. Ocean Coast. Manag. 115, 10-16. doi: 10.1016/j.ocecoaman.2015.04.006

Nicol, S. (2006). Krill, currents, and sea ice: euphausia superba and its changing environment. AIBS Bull. 56, 111-120.

Nikolich, K., and Towers, J. R. (2018). Vocalizations of common minke whales (Balaenoptera acutorostrata) in an eastern North Pacific feeding ground. Bioacoustics 1-12. doi: 10.1080/09524622.2018.1555716
Normile, D. (2019). Japan's exit from whaling group may benefit whales. Science 363, 110-111. doi: 10.1126/science.363.6423.110

Norris, T. F., Dunleavy, K. J., Yack, T. M., and Ferguson, E. L. (2017). Estimation of minke whale abundance from an acoustic line transect survey of the Mariana Islands. Mar. Mamm. Sci. 33, 574-592. doi: 10.1111/mms.12397

Norris, T. F., McDonald, M., and Barlow, J. (1995). Acoustic detections of singing humpback whales (Megaptera novaeangliae) in the eastern North Pacific during their northbound migration. J. Acoust. Soc. Am. 106, 506-514. doi: 10.1121/1. 427071

Northridge, S., Cargill, A., and Coram, A. (2010). Entanglement of Minke Whales in Scottish Waters; An Investigation into Occurrence, Causes and Mitigation. Final Report to Scottish Government, CR/2007/49. St Andrews: University of St Andrews, 57.

O'Connor, S., Campbell, R., Cortez, H., and Knowles, T. (2009). Whale Watching Worldwide: Tourism Numbers, Expenditures and Expanding Economic Benefits. A Special Report from the International Fund for Animal Welfare (IFAW). Yarmouth, MA: International Fund for Animal Welfare, 228.

Ohsumi, S. (1983). Minke whales in the coastal waters of Japan in 1981, with reference to their stock boundary. Rep. Int. Whaling Comm. 33, 365-371.

Oleson, E. M., Calambokidis, J., Burgess, W. C., McDonald, M. A., LeDuc, C. A., and Hildebrand, J. A. (2007). Behavioral context of call production by eastern North Pacific blue whales. Mar. Ecol. Prog. Ser. 330, 269-284. doi: 10.3354/ meps330269

Oswald, J. N., Au, W. W. L., and Duennebier, F. (2011). Minke whale (Balaenoptera acutorostrata) boings detected at the Station ALOHA Cabled Observatory. J. Acoust. Soc. Am. 129, 3353-3360. doi: 10.1121/1.3575555

Parks, S. E., Johnson, M., Nowacek, D., and Tyack, P. L. (2011a). Individual right whales call louder in increased environmental noise. Biol. Lett. 7, 33-35. doi: 10.1098/rsbl.2010.0451

Parks, S. E., Searby, A., Célérier, A., Johnson, M. P., Nowacek, D. P., and Tyack, P. L. (2011b). Sound production behavior of individual North Atlantic right whales: implications for passive acoustic monitoring. Endanger. Species Res. 15, 63-76. doi: 10.3354/esr00368

Parsons, E. C. M., Birks, I., Evans, P. G. H., Gordon, J. G., Shrimpton, J. H., and Pooley, S. (2000). The possible impacts of military activity on cetaceans in West Scotland. Eur. Res. Cetaceans 14, 185-190.

Pastene, L. A., Acevedo, J., Goto, M., Zerbini, A. N., Acuña, P., and Aguayo-Lobo, A. (2010). Population structure and possible migratory links of common minke whales, Balaenoptera acutorostrata, in the Southern Hemisphere. Conserv. Genet. 11, 1553-1558. doi: 10.1007/s10592-009-9944-7

Peel, D., Smith, J. N., and Childerhouse, S. (2018). Vessel strike of whales in australia: the challenges of analysis of historical incident data. Front. Mar. Sci. 5:69. doi: 10.3389/fmars.2018.00069

Perrin, W. F., Mallette, S. D., and Brownell, R. L. Jr. (2018). "Minke whales: Balaenoptera acutorostrata and B. bonaerensis," in Encyclopedia of Marine Mammals, eds B. Wursig, J. G. M. Thewissen, and K. M. Kovacs (Cambridge, MA: Academic Press), 608-613.

Pirotta, E., Booth, C. G., Costa, D. P., Fleishman, E., Kraus, S. D., Lusseau, D., et al. (2018). Understanding the population consequences of disturbance. Ecol. Evol. 8, 9934-9946. doi: 10.1002/ece3.4458

Pirotta, V., Smith, A., Ostrowski, M., Russell, D., Jonsen, I. D., Grech, A., et al. (2017). An economical custom-built drone for assessing whale health. Front. Mar. Sci. 4:425. doi: 10.3389/fmars.2017.00425

Prideaux, G. (2017). Technical Support Information to the CMS Family Guidelines on Environmental Impact Assessments for Marine Noise-generating Activities. Bonn: CMS.

Quintela, M., Skaug, H. J., Øien, N., Haug, T., Seliussen, B. B., Solvang, H. K., et al. (2014). Investigating population genetic structure in a highly mobile marine organism: the minke whale Balaenoptera acutorostrata acutorostrata in the North East Atlantic. PLoS One 9:e108640. doi: 10.1371/journal.pone. 0108640

Rankin, S., and Barlow, J. (2005). Source of the north pacific "boing" sound attributed to minke whales. J. Acoust. Soc. Am. 118, 3346-3351. doi: 10.1121/1. 2046747

Rankin, S., Norris, T. F., Smultea, M. A., Oedekoven, C., Zoidis, A. M., Silva, E., et al. (2007). A visual sighting and acoustic detections of minke whales, Balaenoptera acutorostrata (Cetacea: Balaenopteridae), in Nearshore Hawaiian Waters. Pacific Sci. 61, 395-398. doi: 10.2984/1534-6188(2007)61\%5B395: avsaad\%5D2.0.co;2 
Read, A. J. (2008). The looming crisis: interactions between marine mammals and fisheries. J. Mamm. 89, 541-548. doi: 10.1644/07-mamm-s-315r1.1

Reeves, R., and Notarbartolo di Sciara, G. (2006). The Status and Distribution of Cetaceans in the Black Sea and Mediterranean Sea: Workshop Report-Monaco 5-7 March 2006. Gland: IUCN. Centre for Mediterranean Cooperation.

Reid, K., and Croxall, J. P. (2001). Environmental response of upper trophic-level predators reveals a system change in an Antarctic marine ecosystem. Proc. $R$. Soc. London B Biol. Sci. 268, 377-384. doi: 10.1098/rspb.2000.1371

Reid, K., Croxall, J. P., Briggs, D. R., and Murphy, E. J. (2005). Antarctic ecosystem monitoring: quantifying the response of ecosystem indicators to variability in Antarctic krill. ICES J. Mar. Sci. 62, 366-373. doi: 10.1016/j.icesjms.2004.11.003

Rice, D. W. (1998). Marine Mammals of the World: Systematics and Distribution. Special Publication Number 4. Lawrence, KS: The Society for Marine Mammology.

Risch, D., Castellote, M., Clark, C., Davis, G., Dugan, P., Hodge, L., et al. (2014a). Seasonal migrations of north atlantic minke whales: novel insights from largescale passive acoustic monitoring networks. Mov. Ecol. 2, 1-17. doi: 10.1186/ s40462-014-0024-3

Risch, D., Gales, N. J., Gedamke, J., Kindermann, L., Nowacek, D. P., Read, A. J., et al. (2014b). Mysterious bio-duck sound attributed to the Antarctic minke whale (Balaenoptera bonaerensis). Biol. Lett. 10:20140175. doi: 10.1098/rsbl. 2014.0175

Risch, D., Wilson, S. C., Hoogerwerf, M., van Geel, N. C., Edwards, E. W., and Brookes, K. L. (2019). Seasonal and diel acoustic presence of North Atlantic minke whales in the North Sea. Sci. Rep. 9:3571. doi: 10.1038/s41598-01939752-8

Ryan, C., Leaper, R., Evans, P. G. H., Dyke, K., Robinson, K. P., Haskins, G. N., et al. (2016). "Entanglement: An emerging threat to humpback whales in Scottish waters," in Paper SC/66B/HIM/01 Presented to the International Whaling Commission Scientific Committee, Portoroz, 12.

Rychel, A. L., Reeder, T. W., and Berta, A. (2004). Phylogeny of mysticete whales based on mitochondrial and nuclear data Mol. Phylogenet. Evol. 32, 892-901. doi: 10.1016/j.ympev.2004.02.020

Schofield, O., Ducklow, H. W., Martinson, D. G., Meredith, M. P., Moline, M. A., and Fraser, W. R. (2010). How do polar marine ecosystems respond to rapid climate change? Science 328, 1520-1523. doi: 10.1126/science.1185779

Sivle, L. D., Kvadsheim, P. H., Curé, C., Isojunno, S., Wensveen, P. J., Lam, F.-P. A., et al. (2015). Severity of expert-identified behavioural responses of humpback whale, minke whale, and northern bottlenose Whale to Naval Sonar. Aquat. Mamm. 41, 469-502. doi: 10.1578/am.41.4.2015.469

Sobtzick, S. (2010). Dwarf Minke Whales in the Northern Great Barrier Reef and Implications for the Sustainable Management of the Swim-with Whales Industry. Ph.D. thesis, James Cook University, Townsville.

Song, K.-J. (2016). Current stock situation and measures for the management and conservation of minke whales (Balaenoptera acutorostrata) in Korean waters. Ocean Coast. Manag. 119, 164-168. doi: 10.1016/j.ocecoaman.2015.10.011

Song, K.-J., Kim, Z. G., Zhang, C. I., and Kim, Y. H. (2010). Fishing gears involved in entanglements of minke whales (Balaenoptera acutorostrata) in the East Sea of Korea. Mar. Mamm. Sci. 26, 282-295. doi: 10.1111/j.1748-7692.2009.00340.x

Stafford, K., Citta, J., Moore, S., Daher, M., and George, J. (2009). Environmental correlates of blue and fin whale call detections in the North Pacific Ocean from 1997 to 2002. Mar. Ecol. Prog. Ser. 395, 37-53. doi: 10.3354/meps08362

Stammerjohn, S., Maksym, T., Heil, P., Massom, R. A., Vancoppenolle, M., and Leonard, K. C. (2011). The influence of winds, sea-surface temperature and precipitation anomalies on Antarctic regional sea-ice conditions during IPY 2007. Deep Sea Res. Part II Top. Stud. Oceanogr. 58, 999-1018. doi: 10.1016/ j.dsr2.2010.10.026

Stammerjohn, S., Massom, R., Rind, D., and Martinson, D. (2012). Regions of rapid sea ice change: an inter-hemispheric seasonal comparison. Geophys. Res. Lett. 39.

Stammerjohn, S. E., Martinson, D. G., Smith, R. C., and Iannuzzi, R. A. (2008), Sea ice in the western Antarctic Peninsula region: spatio-temporal variability from ecological and climate change perspectives. Deep Sea Res. Part II Top. Stud. Oceanogr. 55, 2041-2058. doi: 10.1016/j.dsr2.2008.04.026

Stern, S. J., Dorsey, E. M., and Case, V. L. (1990). Photographic catchability of individually identified minke whales (Balaenoptera acutorostrata) of the San Juan Islands, Washington and the Monterey Bay Area, California. Rep. Int. Whaling Comm. 12, 127-133.
Stoeckl, N., Birtles, A., Farr, M., Mangott, A., Curnock, M., and Valentine, P. (2010). Live-aboard dive boats in the great barrier reef: regional economic impact and the relative values of their target marine species. Tour. Econ. 16, 995-1018. doi: $10.5367 /$ te. 2010.0005

Tetley, M. J., Mitchelson-Jacob, E. G., and Robinson, K. P. (2008). The summer distribution of coastal minke whales (Balaenoptera acutorostrata) in the southern outer Moray Firth, NE Scotland, in relation to co-occurring mesoscale oceanographic features. Remote Sens. Environ. 112, 3449-3454. doi: 10.1016/j. rse.2007.10.015

Thomson, J. A., Cooper, A. B., Burkholder, D. A., Heithaus, M. R., and Dill, L. M. (2013). Correcting for heterogeneous availability bias in surveys of longdiving marine turtles. Biol. Conserv. 165, 154-161. doi: 10.1016/j.biocon.2013. 06.005

Tscherning, K., Helming, K., Krippner, B., Sieber, S., and y Paloma, S. G. (2012). Does research applying the DPSIR framework support decision making? Land Use Policy 29, 102-110. doi: 10.1016/j.landusepol.2011.05.009

Tubelli, A. A., Zosuls, A., Ketten, D. R., Yamato, M., and Mountain, D. C. (2012). A prediction of the minke whale (Balaenoptera acutorostrata) middle-ear transfer function. J. Acoust. Soc. Am. 132:3263. doi: 10.1121/1.4756950

Tulloch Ayesha, I. T., Gordon, A., Runge, C. A., and Rhodes, J. R. (2019). Integrating spatially realistic infrastructure impacts into conservation planning to inform strategic environmental assessment. Conserv. Lett. e12648. doi: 10. $1111 /$ conl.12648

Valentine, P. S., Birtles, A., Curnock, M., Arnold, P., and Dunstan, A. (2004). Getting closer to whales-passenger expectations and experiences, and the management of swim with dwarf minke whale interactions in the Great Barrier Reef. Tour. Manag. 25, 647-655. doi: 10.1016/j.tourman.2003.09.001

van der Hoop, J. M., Moore, M. J., Barco, S. G., Cole, T. V. N., Daoust, P.-Y., Henry, A. G., et al. (2012). Assessment of management to mitigate anthropogenic effects on large whales. Conserv. Biol. 27, 121-133. doi: 10.1111/j.1523-1739. 2012.01934.x

van Waerebeek, K., André, M., Sequeira, M., Martin, D., Robineau, D., Collet, A. S., et al. (1999). Spatial and temporal distribution of the minke whale Balaenoptera acutorostrata (Lacepede, 1804), in the southern northeast Atlantic Ocean and the Mediterranean Sea, with reference to stock identity. J. Cetacean Res. Manag. $1,223-237$.

Víkingsson, G. A., and Heide-Jørgensen, M. P. (2015). First indications of autumn migration routes and destination of common minke whales tracked by satellite in the North Atlantic during 2001-2011. Mar. Mamm. Sci. 31, 376-385. doi: $10.1111 / \mathrm{mms} .12144$

Williams, R., Kelly, N., Boebel, O., Friedlaender, A. S., Herr, H., Kock, K.-H., et al. (2014). Counting whales in a challenging, changing environment. Sci. Rep. 4:4170. doi: $10.1038 /$ srep04170

Yamato, M., Ketten, D. R., Arruda, J., Cramer, S., and Moore, K. (2012). The auditory anatomy of the minke whale (Balaenoptera acutorostrata): a potential fatty sound reception pathway in a baleen whale. Anat. Rec. Adv. Integr. Anat. Evol. Biol. 295, 991-998. doi: 10.1002/ar. 22459

Zerbini, A. N., Secchi, E. R., Siciliano, S., and Simoes-Lopes, P. (1996). The dwarf form of the minke whale Balaenoptera acutorostrata Lacépède, 1804, in Brazil. Rep. Int. Whaling Comm. 46, 333-340.

Zerbini, A. N., Waite, J. M., Laake, J. L., and Wade, P. R. (2006). Abundance, trends and distribution of baleen whales off Western Alaska and the central Aleutian Islands. Deep Sea Res. Part I Oceanogr. Res. Pap. 53, 1772-1790. doi: 10.1016/j.dsr.2006.08.009

Conflict of Interest Statement: TN was employed by Bio-Waves Inc.

The remaining authors declare that the research was conducted in the absence of any commercial or financial relationships that could be construed as a potential conflict of interest.

Copyright (๑) 2019 Risch, Norris, Curnock and Friedlaender. This is an open-access article distributed under the terms of the Creative Commons Attribution License (CC BY). The use, distribution or reproduction in other forums is permitted, provided the original author(s) and the copyright owner(s) are credited and that the original publication in this journal is cited, in accordance with accepted academic practice. No use, distribution or reproduction is permitted which does not comply with these terms. 